June - 2009

\title{
The Retention of Experienced Faculty in Online Distance Education Programs: Understanding Factors that Impact their Involvement
}

\author{
Tim Green \\ California State University, Fullerton, USA \\ Jeffery Alejandro and Abbie H. Brown \\ East Carolina University
}

\begin{abstract}
The study sought to determine factors that affect faculty decisions regarding their involvement in teaching online distance education courses. A survey was administered to online distance education faculty across the United States to determine those factors that encourage or discourage them from continuing to teach online courses. The factors were examined and reported from the standpoint of each of four faculty groups: (1) tenured, (2) tenure-track, (3) full-time nontenured/fixed term, and (4) part-time/adjunct. From the survey responses $(N=135)$, a list of retention strategies that university administrators may use for retention of online distance education faculty are offered.
\end{abstract}

Keywords: Online distance education administration; faculty retention; strategies for retaining faculty

\section{Introduction}

Over the past five years, the Sloan Consortium has published an annual report focusing on the state of online learning in U.S. higher education. The most recent published report, Online Nation: Five Years of Growth in Online Learning, describes data received from 2,535 institutions $(4,491$ degree-granting institutions open to the public were surveyed). The institutions were asked to respond to questions regarding the number of students enrolled in online learning at their institution, the courses or programs these students were enrolled in, and the barriers that prohibited widespread adoption of online learning at their institution. Based on data collected, more than two-thirds of the institutions reported having some form of online offerings, with the majority of the institutions providing programs that are offered fully online. The number of students in fall 2006 taking at least one online course represented almost 20 percent of all students enrolled at these institutions, which is an increase of $10.1 \%$ since 2002 (Allan \& Seaman, 2007). These numbers indicate that future growth in online learning in the U.S. is likely 
to continue significantly in the years to come. It appears that this growth is being planned for, or at least considered, by a number of higher education institutions.

As institutions consider and plan, a variety of issues must be addressed if their online programs are to be successful. One major issue is faculty turnover, particularly among part-time, adjunct faculty. Faculty turnover is costly. This cost can involve course adaptation and redevelopment, faculty training, and increased staff support (Pferdehirt, Smith, \& Al-Ashakr, 2005) In addition to being detrimental to an institution's budget, faculty turnover can also be damaging to its reputation. Institutions, therefore, should be proactive in developing a system focused on retaining high quality distance education faculty (Pferdehirt, Smith, \& Al-Ashakr). Before an institution is capable of developing an effective distance education faculty retention system, factors that impact faculty participation in distance education must first be understood.

\section{Theoretical Framework}

A significant body of literature exists that theorizes and reports research on motivating factors, discouraging factors, and encouraging factors influencing faculty involvement in the teaching of online distance education courses. The literature review provided in this section is by no means an exhaustive examination of the body of literature; however, the literature reviewed does provide a detailed summary of prior studies focusing on motivating factors, discouraging factors, and encouraging factors that influence faculty to teach online distance education courses.

\section{Motivating Factors}

Some of the motivating factors listed in the research (Andersen, 2004; Hiltz, Kim, \& Shea, 2006; Keeten, 2000; Schnitzer \& Crosby, 2003; Theall, 1999; Townsend \& Hauss, 2002) are flexible scheduling, opportunity to experiment with new pedagogy, computing skill level and opportunity to learn new technology, natural curiosity, marketability of skills, opportunity to share knowledge, and career development. Other motivators include university sponsored incentives and policies (Gannon-Cook \& Ley, 2004; Moore \& Anderson, 2003).

Many faculty members are motivated to teach distance education courses because of the various incentives that they receive for doing so. According to Moore and Anderson (2003), "incentives that have been identified with respect to distance education appear to be of three major types: (1) situational aspects or characteristics of the work environment that facilitate participation, (2) inducements offered by the institution expressly to entice faculty to participate, and (3) intrinsic rewards returned for participation" (p. 557). Situational aspects or characteristics may include availability of technology training and assistance, departmental commitment to distance education, and/or a well-developed support system. Inducements offered by the institution may include increase in salary, promotion credit, and/or release time. Intrinsic rewards may include personal/professional growth, career advancement, personal challenge, and/or personal satisfaction for a job well done. 
In regards to situational aspects, Theall (1999) identified eight basic characteristics of campus culture that motivate faculty to teach: (1) a high level of administrative commitment and support; (2) faculty involvement, shared values, and a sense of ownership; (3) a broader definition of scholarship; (4) teaching demonstration or pedagogical colloquium as part of the hiring process; (5) frequent interaction, collaboration, and community among faculty; (6) a faculty development program or campus teaching center; (7) supportive and effective department chairs; and (8) a rigorous evaluation of teaching that is connected to tenure and promotion decisions. GannonCook and Ley's (2004) review of prior research showed that university policies that create positive, motivating conditions for faculty participation and that eliminate inhibitors could sustain and stimulate faculty participation in distance education. They found three leading motivators of distance education faculty in most studies: (1) personal motivation to use technology, (2) ability to reach new audiences, and (3) presence of strong technical and administrative support. Faculty who sense a serious commitment to quality from their institution will have a strong personal investment in the distance education program's future (Allan \& Seaman, 2007). Faculty members are motivated to participate when they see how their institutions value distance education, how distance education benefits their careers, and how teaching via distance fits their lives.

As for inducements, faculty wants to know what the personal rewards may be. Full-time, parttime, and adjunct faculty members are all involved in online teaching, with adjunct faculty becoming more involved in teaching in higher education settings (Schnitzer \& Crosby, 2003). Townsend and Hauss (2002) found that two of the main reasons adjunct instructors teach distance education courses were to gain teaching experience and for additional income. This was supported when Gannon-Cook and Ley (2004) examined prior research studies and found that most listed the presence of monetary reward systems as an inducement offered by institutions to recruit distance education faculty. Shea (2007) reports that part-time faculty members may be more inclined to teach online because it accommodates other life needs, potentially provides more free time for other professional activities, and reduces commuting time. Andersen (2004) found tenure-track faculty more likely to teach distance education courses if they know their efforts will be counted towards tenure. Seldom will faculty participate in activities that take time and resources away from furthering their careers, especially when trying to get tenured at an institution. Schifter (2000b) found that faculty compensation is an important factor in faculty motivation. Full-time instructors who participate in distance education are sometimes compensated with release time, overload pay, new computer or laptop, travel funds, or access to a teaching assistant.

As mentioned previously, intrinsic rewards may include personal growth and the satisfaction gained from a job well done. Ko and Rossen (2003) wrote that some faculty teach distance education courses because they seek a heightened awareness of teaching and a connection to a global community of educators. They desire to help further the advancement of knowledge and society as a whole. Some faculty members teach distance education courses for the students. McKenzie et al. (2000) determined that some faculty migrate to distance education because of their wish to interact with students more frequently and because students had asked consistently for courses to be offered online. This was later confirmed by Belcheir and Cucek (2002), who 
found that faculty was more likely to participate in online classes if they could see that students would benefit from them. The motivating factor here was an opportunity for faculty to share knowledge and expand their field of study.

\section{Discouraging Factors}

Disincentives cited within the professional literature (Belcheir \& Cucek, 2002; Bower, 2001; Brown, 2003; Giannoni \& Tesone, 2003; Moore \& Anderson, 2003; Passmore, 2000; Schweber, Kelley, \& Orr, 1998; Sumrall, 2002) included the following: the time and effort teaching online requires (compared to face-to-face courses); the lack of financial compensation in comparison to work performed; the lack of institutional support; the lack of experience with online teaching; the lack of recognition for efforts made in online teaching; and the lack of sufficient technical training.

Sumrall (2002) found that one of the primary obstacles for faculty participation in distance education is the lack of fit with university missions and goals (institutional fit). The absence of institutional fit often leads to a lack of institutional support. Keeton (2002) discovered that institutions that failed to convince faculty that the technology is reliable and that the quality is at least equal to the traditional methods, that do not provide faculty with adequate time to develop and maintain distance education courses, and that do not establish a clear vision of distance education were not likely to recruit quality faculty to teach in their distance education programs.

Shea (2007) reported that the number of times an instructor has taught online has an impact on their interest in continuing to do so. Less experienced instructors were reticent to engage in online teaching due to feeling under-prepared in terms of familiarity with online pedagogy and having fewer opportunities to observe online teaching modeled by others. Issues of compensation were also an issue among less experienced instructors.

Another reason that faculty is sometimes reluctant to participate in distance education is because they feel their return on investment is questionable, especially with respect to tenure and promotion (Passmore, 2000; Shea, 2007). Faculty at four-year institutions also indicated that online teaching can be confusing and that the time necessary to revise online courses may not be available.

The literature further suggests that faculty may opt not to teach distance education courses because they do not receive adequate compensation, release time, materials, and equipment to offer quality distance education courses (Bower, 2001; Schifter 2000a, b). Faculty with higher computer skills may also be less inclined to teach online due to their feeling that they received inadequate compensation and/or recognition for the task (Shea, 2007).

\section{Encouraging Factors}

The proposed retention strategies mentioned in the literature (Fredrickson et al., 2000; Schweber, Kelley, \& Orr, 1998) included continuous training, mentoring, opportunities for distance 
education faculty to collaborate with campus faculty, and assimilation into the university community. Faculty will stay if they feel welcomed, wanted, and needed.

Gaillard-Kenney (2006) suggests that after institutions hire adjunct faculty, they should schedule an orientation to help the adjuncts feel part of the organization. Following the orientation process, provisions should be made for subsequent faculty development opportunities. These things need to be done in order to prevent the adjunct faculty from feeling isolated and to ensure quality of teaching. Also, adjuncts should be integrated into the institution. One way to accomplish this is to offer adjuncts opportunities to interact with full-time faculty members. Adjunct faculty members should be provided with opportunities for collaboration in order to facilitate scholarly exchanges and the building of a teaching community. Also, a mentoring program should be established to further assimilate adjuncts into the institution's culture.

According to Schweber, Kelley, and Orr (1998), one way to retain distance education faculty is to provide them with continuous training in the form of workshops. The workshop topics should be varied (i.e., Authorware, online course development, course management systems, computer literacy). Training should be at no cost to the faculty and faculty should receive a stipend for each workshop that they complete. Keeton (2002) advises distance education administrators to do the following: (1) convince faculty that the technology is reliable and the quality is at least equal to the traditional methods, (2) provide time to develop and maintain distance education courses, (3) examine and evaluate distance education, (4) establish peer models within departments, and (5) establish a clear vision of distance education.

One way to establish peer models is through mentoring. Mentoring is sometimes seen as a quality control tool. Such is the case when a more experienced faculty member observes and assists another faculty member in migrating their course from face-to-face to online. Their chief objective is to make sure the new course format meets certain standards. Aside from its role as a quality control tool, mentoring can be a sign of a university's commitment to ongoing professional development for its faculty (Mandernach et al., 2005). This can be a useful retention strategy. Mentoring is a way to assimilate new faculty into university culture and to make them feel welcomed. Also, it allows seasoned faculty to share their skills with novices and to enhance personal self-satisfaction (Parker, 2003). A mentoring strategy can thus help to retain both the new and the established faculty member.

\section{Research Method and Participants}

To determine more specifically which factors have the greatest impact on faculty with regard to their approach to teaching online, the authors developed and administered a survey to a sample of online distance educators across the United States.

\section{Participants}

The sample for this study comes from the population of faculty active in online distance education. The sample was drawn from members of the Distance Education Online Symposium 
listserv as well as from online distance education faculty members who currently teach or who have taught at East Carolina University and the California State University, Fullerton. It is difficult to ascertain the exact number of faculty the survey reached due to the survey being sent to a listserv; despite this, we can say that the survey reached at least 500 faculty members (including the lists from East Carolina University and California State University, Fullerton). The study sample was selected based on its members being actively engaged in teaching online distance education courses.

\section{Data Collection Protocol}

Based on the review of the literature, a survey was designed to identify those factors critical to the retention of online distance education faculty. Participants were asked to respond to a series of closed and open-ended questions that were designed to collect background information as well as to rate 10 statements about motivating factors, 11 statements about discouraging factors, and seven statements about encouraging factors. The ratings were as follows: strongly agree, agree, neutral, disagree, and strongly disagree. Following each set of statements, participants were asked to indicate which of the factors in the set impacted their decision to teach distance education courses the most. Participants were also prompted to list additional factors not specifically stated in the survey.

Prior to the distribution of the survey, four distance education experts reviewed the instrument (two faculty members, a distance education administrator, and an instructional designer). Based on the reviewers' suggestions, minor changes were made to the instrument. For ease of distribution and data collection, the survey was posted online. After reviewing several web-based survey tools, Perseus Survey Solutions software was selected for its ease of use and data collection capabilities. Because all survey participants were experienced distance educators, it was felt that an online survey would provide a relatively easy and reliable method of response.

\section{Data Collection and Analysis Procedures}

A link to the online survey was distributed through email to solicit participation. Included in the email was a message describing the purpose of the study and the importance of participating in it; also, there was a statement to assure the respondents of confidentiality. Two weeks after the initial emailing, a follow-up email was sent to the Distance Education Online Symposium listserv reminding members about the survey. After the survey link had been open for 30 days, the responses were downloaded and data analysis began. Descriptive statistics were calculated and then examined for trends.

\section{Respondent Profile}

The survey invitation elicited 135 completed surveys from the participant population. The respondents represented 23 different universities. They were somewhat evenly divided among the four faculty groups: (1) adjunct/part-time, 28.15\%; (2) full-time non-tenured, 22.96\%; (3) tenure- 
track, 25.93\%; and (4) tenured, 22.96\%. Most had been teaching distance education courses for 13 years $(52.59 \%)$, followed by $34.81 \%$ for $4-6$ years, $6.67 \%$ for $7-9$ years, and $5.93 \%$ for 10 or more years. Forty percent of the group taught only distance education courses, while $60 \%$ taught both distance education and face-to-face courses.

\section{Results and Findings}

This section is organized according to the various faculty groups that make up the participants who were surveyed: all faculty, adjunct/part time, full-time non-tenured, and tenured.

\section{All Faculty}

As a whole, faculty members are motivated to teach online distance education courses for the following reasons: flexible working conditions (82.22\%), opportunity to use technology (71.11\%), opportunity to share knowledge with others (70.37\%), intellectual challenge $(67.41 \%)$, career development/advancement (58.52\%), and opportunity to gain teaching experience (54.81\%). A majority (54.07\%) of the respondents cited that their concerns about time commitment might discourage them from teaching distance education courses. Numerous respondents listed the lack of sufficient financial compensation in comparison to workload (48.89\%), concerns about workload (48.15\%), and lack of institutional support $(43.70 \%)$ as possible discouraging factors. Factors that most respondents stated would encourage them to continuing teaching distance education courses are the following: continuous training provided by the university $(73.33 \%)$, fair financial compensation in comparison to workload $(72.59 \%)$, increased institutional support $(71.85 \%)$, opportunity to assist with course/program development $(71.85 \%)$, and mentoring from veteran distance education instructors $(51.85 \%)$.

\section{Adjunct/Part-Time Faculty}

Adjunct/part-time faculty as a group is similar to the other groups in that they are motivated by the flexible working conditions $(97.37 \%)$, the opportunity to share knowledge with others (89.47\%), the opportunity to use technology (86.84\%), the opportunity to gain teaching experience $(78.95 \%)$, the opportunity for career development/advancement $(71.05 \%)$ and the intellectual challenge $(71.05 \%)$. Unlike the other groups, however, adjunct/part-time faculty members are motivated by the possibility of increasing personal income $(78.95 \%)$ and a sense of loyalty to the university (52.63\%). Based on their responses, adjunct/part-time faculty members are discouraged by the lack of sufficient financial compensation in comparison to workload $(50.00 \%)$ and by concerns about the quality of students $(50.00 \%)$. While this group indicated that they are encouraged by all the factors listed on the survey, they were especially motivated by fair financial compensation in comparison to workload (89.47\%), increased institutional support (81.58\%), and the opportunity to assist with course/program development (81.58\%). 


\section{Full-Time Non-Tenured Faculty}

When it comes to motivating factors, the full-time non-tenured faculty is no different from the other groups. Most are motivated by flexible working conditions (83.87\%), the opportunity to use technology $(80.65 \%)$, the opportunity to share knowledge with others $(77.42 \%)$, the intellectual challenge (74.19\%), the opportunity for career development/advancement (67.74\%), and the opportunity to gain teaching experience $(58.06 \%)$. In regard to discouraging factors, the full-time non-tenured faculty is also similar to the other groups. Their concerns about workload $(54.84 \%)$ and their concerns about time commitment (51.61\%) are the factors that are most likely to discourage them from teaching distance education courses. Most full-time non-tenured faculty members are encouraged to continuing teaching by the following factors: opportunity to assist with course/program development $(80.65 \%)$, continuous training provided by the university (64.52\%), fair financial compensation in comparison to workload $(61.29 \%)$, and increased institutional support (58.06\%).

\section{Tenure-Track Faculty}

The factors that motivate most tenure-track faculty are flexible working conditions $(77.14 \%)$, intellectual challenge (62.86\%), opportunity to share knowledge with others $(57.14 \%)$, and career development/advancement opportunities (54.29\%). Unlike adjunct/part-time and full-time nontenured faculty groups, less than half of the tenure-track faculty is motivated by gaining additional teaching experience $(48.57 \%$ ) or by the opportunity to use technology (48.57\%). Like the other groups, over half of the tenure-track faculty can be discouraged by their concerns about workload (51.43\%). It appears that the tenure-track faculty group is highly encouraged by continuous training provided by the university (77.14\%), increased institutional support (71.43\%), fair financial compensation in comparison to workload (68.57\%), and opportunities to assist with course/program development $(62.86 \%)$. Few cited being encouraged by additional opportunities to interact with the full university community $(28.57 \%)$.

\section{Tenured Faculty}

Many tenured faculty members are motivated by the intellectual challenge $(70.97 \%)$, followed by the opportunity to use technology (67.74\%), the flexible working conditions $(67.74 \%)$, and the opportunity to share knowledge with others $(54.84 \%)$. Most of the tenured faculty cited a lack of sufficient financial compensation in comparison to workload (58.06\%), concerns about time commitment $(51.61 \%)$, and concerns about quality of students $(51.61 \%)$ as factors that would discourage them from teaching distance education courses in the future. Also, most cited the lack of personal connection with the university $(51.61 \%)$ as a discouraging factor. They were the only group to do so. As with the other groups, most of the tenured faculty agreed that continuous training provided by the university $(77.42 \%)$, increased institutional support $(74.19 \%)$, fair financial compensation in comparison to workload (67.74\%), and opportunities to assist with course/program development (61.29\%) would encourage them to continue teaching distance education courses. 


\section{Summary}

\section{All Faculty}

Qualified and experienced faculty members are an important resource for online distance education programs. Universities must make a concerted effort to retain them. This research study found that online distance education faculty as a whole are highly motivated by situational incentives, such as flexible working conditions and the opportunity to use technology. They are also motivated by intrinsic rewards, such as the opportunity to share knowledge with others, the intellectual challenge, their career development/advancement, and the opportunity to gain teaching experience. The major factor that might discourage them from teaching distance education courses is their concern about time commitment. Based on these factors, some possible retention strategies may include the provision of continuous training, of mentoring from veteran distance education instructors, and of opportunities to assist with course/program development. Because most faculty members are motivated by flexible working conditions, they should be allowed to have some say about their course load and schedule. The findings of this study support the findings of other studies regarding motivating factors for online distance education instructors.

\section{Adjunct/Part-Time Faculty}

The motivating factors that set the adjunct/part-time faculty apart from the other groups were increased personal income and a sense of loyalty to the university. They and the full-time nontenured faculty were the only two groups to note that they want to gain additional teaching experience. This group wants to feel that they are a vital part of the university. Like the other groups studied, their responses expressed a concern about the lack of sufficient financial compensation in comparison to workload. The adjunct/part-time faculty also cited that their concerns about the quality of students might discourage them. Possible retention strategies for this group are fair compensation plans, long-term teaching contracts, orientation programs, mentoring programs, and opportunities to assist with course/program development.

\section{Full-Time Non-Tenured Faculty}

Like the other groups, full-time non-tenured faculty members are motivated by flexible working conditions, the opportunity to use technology, the opportunity to share knowledge with others, the intellectual challenge, their career development/advancement, and the opportunity to gain teaching experience. Their chief concerns are workload and time commitment. The retention strategies that could encourage them to keep teaching via distance education are opportunities to assist with course/program development, continuous training, fair financial compensation, and increased institutional support. 


\section{Tenure-Track Faculty: Untenured}

The factors that motivate most tenure-track faculty are mainly intrinsic rewards. They are motivated by flexible working conditions, intellectual challenge, opportunity to share knowledge with others, and career development/advancement opportunities. Unlike adjunct/part-time and full-time non-tenured faculty groups, less than half of the tenure-track faculty is motivated by gaining additional teaching experience or the opportunity to use technology. Like the other groups, over half of the tenure-track faculty can be discouraged by their concerns about workload. Providing them with continuous training, increased institutional support, fair financial compensation, and opportunities to assist with course/program development may retain most tenure-track faculty.

\section{Tenured Faculty}

Like the tenure-track faculty, most tenured faculty members are motivated by intrinsic rewards. They like the intellectual challenge, flexible working conditions, and opportunity to share knowledge with others. Tenured faculty can be discouraged by the lack of sufficient financial compensation in comparison to the workload as well as by concerns about time commitment and about the quality of students. They were the only group to indicate the lack of personal connection with the university as a discouraging factor. As with all the other groups, the suggested retention strategies for tenured faculty are continuous training, increased institutional support, fair financial compensation, and opportunities to assist with course/program development. An additional retention strategy for this group may be the implementation of an online faculty community.

\section{Implications and Future Directions}

As mentioned earlier, a significant portion (69\%) of traditional and non-traditional colleges and universities in the United States believe that student demand for online courses and programs is continuing to grow (Allan \& Seaman, 2007). Almost all institutions (83\%) currently offering online distance education expect their enrollments to continue to increase (Allan \& Seaman). With this continued demand, the need to retain experienced faculty to teach these courses is paramount. Institutions will have to develop a systematic plan for recruiting, hiring, and developing online distance education faculty. To be successful, there must be a commitment to educational quality as well as a commitment from all levels of an institution.

Based on the survey results, the following strategies are recommended as part of an overall system to develop and retain experienced faculty.

1. Provide an institutional support system that includes the following: 
- $\quad$ Training for all levels of online distance education instructors from the beginners to veteran distance educators who are interested in continuing their professional development. It is important not to forget the veteran distance educators. Keeping training opportunities available to this group will help them stay 'fresh' and let them know they are being considered and valued. Many institutions have faculty development centers that can provide this type of training.

- Assistance in course development. This includes the overall instructional design of an entire course to the development of instructional media. Faculty may not have the expertise and/or the desire to create effective instructional media. Instructional designers and media developers can help faculty to develop and use instructional media that meets the needs of their students.

- Mentors for beginning online distance educators. A process needs to be in place where veteran distance educators serve as mentors to provide guidance and support on various issues. An important element of this process is course observation-a veteran distance educator visiting his or her mentee to provide feedback. This process is similar to on-campus relationships where senior faculty members are asked to observe junior faculty as they are teaching and to provide feedback.

2. Faculty should be compensated at a level that they feel is fair based on the perceived (and often real) increased workload associated with developing and teaching an online distance education course. This is especially important for adjunct faculty who are able to easily move to another institution because there is no on-going relationship. This strategy leads directly to the next strategy, which is to consider providing veteran (successful) adjunct faculty with a year-long or multiyear commitment. This can help adjunct faculty feel valued and thus more committed to continue teaching at a particular institution.

3. Determine how online distance education courses fit into the retention and promotion process for full-time tenure-track faculty. One extremely important element is to ensure that student evaluation instruments for distance education courses are developed thoughtfully and that data is collected carefully. Course facilitation and course technology are two separate issues. Faculty should only be evaluated based on how well they facilitated the course, not on whether a particular course management system worked efficiently (which often is not within the control of a faculty member).

4. Ensure that online distance education students are adequately supported. Faculty should be able to focus on teaching and not have to be the frontline support for students facing technical issues. When faculty have to deal with frontline support issues (e.g. technical issues with course management systems) it detracts from the time spent facilitating a course. Faculty should also be supported when they experience technical issues.

5. Develop a sense of community with online distance education instructors. It is important to help instructors (especially adjunct instructors who may only teach at a distance) feel connected to the university. Regular communication with online distance education faculty is a must. Their input should be sought on various issues regarding online courses and programs. A system should be in place where online faculty can communicate and share ideas with other online faculty at the institution. This can be accomplished through a variety of Internet-based tools (e.g., listserv, blog, discussion board). 
While the authors believe the study results help confirm (and expand) the results from similar studies, which themselves provide a reasonable basis for understanding the factors critical to the retention of experienced online distance educators (especially adjunct faculty), there is a need to conduct additional research in this area. Given more time and greater resources, the survey, or a similar one, might be made available to a larger pool of participants by expanding the invitation to include educators who may not subscribe to the DEOS listserv or who may not teach at East Carolina University or California State University, Fullerton. An expansion of the data gathered through an additional survey would allow additional elements to be identified, such as gender of faculty participants, university enrollment, online distance education enrollment, and technology resources. These data could then be used to conduct more robust statistical analyses. Furthermore, with a larger sample, statistical comparisons of the various subgroups would be more robust and helpful in making stronger generalizations. Finally, interviews with individuals or focus group studies addressing the same or similar factors as those addressed in the survey may provide greater insight into those factors that affect educators' approaches to teaching in an online distance education environment. 
The Retention of Experienced Faculty in Online Distance Education Programs: Understanding Factors that Impact their Involvement - Green, Alejandro, and Brown

\section{References}

Allan, E., \& Seaman, J. (2007). Online nation: Five years of growth in online learning. Needham, MA: The Sloan Consortium. Retrieved December 21, 2007, from http://www.sloan-c.org/publications/survey/pdf/online nation.pdf

Andersen, D. (Ed.) (2004). Digital scholarship in the tenure, promotion, and review process. Armonk, NY: M.E. Sharpe.

Belcheir, M., \& Cucek, M.(2002). Faculty perceptions of teaching distance education courses. Research Report: 2002. Boise, ID: Boise State University. (ERIC Document Reproduction Service No. ED 480925)

Bower, B. (2001). Distance education: Facing the faculty challenge. The Online Journal of Distance Learning Administration, 6(2). Retrieved November 23, 2006, from http://www.westga.edu/ distance/ojdla/summer42/bower42.html

Brown, D. (2003). Developing faculty to use technology. Boston, MA: Anker Publishing Company.

Fredrickson, E., Pickett, A., Shea, P., Pelz, W., \& Swan, K. (2000). Factors influencing faculty satisfaction with asynchronous teaching and learning in the SUNY learning network. Journal of Asynchronous Learning Networks, 4(3). Retrieved November 1, 2007, from http://www.alnresearch.org/Data_Files/articles/full_text/fs-fredericksen.htm

Gannon-Cook, R., \& Ley, K. (2004, October 20). What's driving faculty participation in distance education? Paper presented at the 27th Annual Meeting of the Association for Educational Communications and Technology, Chicago, IL.

Giannoni, D., \& Tesone, D. (2003). What academic administrators should know to attract senior level faculty members to online learning environments. Online Journal of Distance Education Administration, 6(1). Retrieved October 21, 2007, from http://www.westga.edu/ distance/ojdla/spring61/giannoni61.htm

Hiltz, S. R., Kim, E., \& Shea, P. (2006). Faculty motivators and demotivators for teaching online: Results of focus group interviews at one university. Proceedings of the 40th Annual Hawaii International Conference on System Sciences.

Keeton, C. (2000). Institutional structures that influence faculty to participate in distance education. Dissertation Abstracts International, 61(10), 3840A. (UMI No. AAT 9993226)

Ko, S., \& Rossen, S. (2003). Teaching online: A practical guide. Boston, MA: Houghton Mifflin. 
Mandernach, B., Donnelli, E., Dailey, A., \& Schulte, M. (2005). A faculty evaluation model for online instructors: Mentoring and evaluation in the online classroom. Online Journal of Distance Learning Administration, 8(3). Retrieved October 21, 2007, from http://www.westga.edu/ distance/ojdla/fall83/mandernach83.htm

McKenzie, B., Mims, N., Bennett, E., \& Waugh, M. (Winter, 2000). Needs, concerns and practices of online instructors. Online Journal of Distance Learning Administration, 3(3). $\begin{array}{llll}\text { Retrieved October } & \text { 1, 2007, from }\end{array}$ http://www.westga.edu/ distance/ojdla/fall33/mckenzie33.html

Moore, G., \& Anderson, W. (Eds) (2003). Handbook of distance education. Mahwah, NJ: Lawrence Erlbaum Associates.

Parker, A. (2003). Motivation and incentives for distance faculty. Online Journal of Distance Learning Administration, 6(3). Retrieved November 12, 2006, from http://www.westga.edu/ distance/ojdla/fall63/parker63.htm

Passmore, D. (2000). Impediments to adoption of web-based course delivery among university faculty. ALN Magazine, 4(2). Retrieved November 30, 2006, from http://www.sloanc.org/publications/magazine/v4n2/passmore.asp

Pferdehirt, W., Smith, T., \& Al-Ashkar, K. (2005). The University of Wisconsin-Madison's Master of Engineering in Professional Practice (MEPP) program: The road to quality online graduate engineering education. Journal of Asynchronous Learning Networks, 9(2). Retrieved

September 28, 2006, from http://www.sloanc.org/publications/jaln/v9n2/pdf/v9n2_pferdehirt.pdf

Schifter, C. (2000a). Compensation models in distance education. The Online Journal of Distance Learning Administration, 3(1). Retrieved November 19, 2006, from http://www.westga.edu/ distance/schifter31.html

Schifter, C. (2000b). Factors influencing faculty participation in distance education: A factor analysis. Education at a Distance, 13(1). Retrieved November 19, 2006, from http://www.usdla.org/html/journal/JAN00_Issue/Factors.htm

Schnitzer, M., \& Crosby, L. (2003). Recruitment and development of online adjunct instructors. The Online Journal of Distance Learning Administration. Retrieved December 21, 2007, from http://www.westga.edu/ distance/ojdla/summer62/crosby_schnitzer62.html

Schweber, C., Kelley, K., \& Orr, G. (1998, August). Training and retaining faculty for online courses: Challenges and strategies. Paper presented at the Annual Conference on Distance Teaching and Learning, Madison, WI. 
Shea, P. (2007). Bridges and barriers to teaching online college courses: A study of experienced online faculty in thirty-six colleges. Journal of Asynchronous Learning Networks, 11(2). Retrieved February 18, 2008, from http://www.sloanc.org/publications/jaln/v11n2/pdf/v11n2_shea.pdf

Sumrall, J. (2002). Factors which influence faculty attitudes and perceptions of distance education in analytical subject areas. Dissertation Abstracts International, 65(06), 2081A. (UMI No. 3135309)

Theall, M. (Ed.) (Summer, 1999). Motivation from within: Approaches for encouraging faculty and students to excel. New Directions for Teaching and Learning, 78. San Francisco, CA: Jossey Bass.

Townsend, R., \& Hauss, M. (2002). The 2002 AHA-OAH survey of part-time and adjunct faculty. Perspectives Online. Retrieved October 6, 2006, from http://www.historians.org/perspectives/issues/2002/0210/0210aha3.cfm.
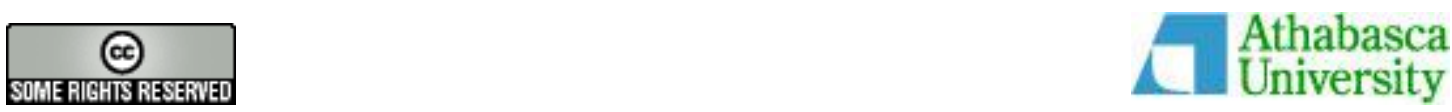